\title{
Genome Games: Market Challenges, Investment Opportunities and Patent Battles
}

\author{
Kristina A. Khodova \\ Skolkovo Foundation, Moscow, Russia
}

Dr. Kristina A. Khodova, Skolkovo Innovation Center, Nobel

Phone: +7 (916) 438-29-54

E-mail: kris.khodova@gmail.com

\section{Summary}

Recent improvements in targeted genome editing technologies have opened new potential therapeutic applications in different medical conditions. Despite the fact that most of these technologies are still at early implementation phase, they already demonstrate a high therapeutic potential which may change treatment methodology for many severe diseases, and exert a significant influence upon market landscape and human population in general. However, some major issues and risks

remain in the field, i.e., whether appropriate products and results will meet expectations of scientists, engineers and investors, and what risks could be anticipated for the registration procedures and introduction of original products into clinical practice.

\section{Keywords}

Genome editing, investment, startups, research \& development, intellectual property.
It took millions of years for apes to evolve into humans. It may take only a century for humans to change again.

Unknown author

Recent advent and subsequent improvements in genome editing techniques have dramatically changed public attitudes towards implementation of biotechnology and created novel opportunities for a variety of technological startup companies. None of the most influential publications in the world have overlooked growing interest for for genome editing in various fields of medicine, agriculture, industrial biotech, etc. Booming headlines have announced future victories over severe diseases, comparing recent achievements in genetic engineering to invention of electricity, antibiotics, rocketry, and the Internet. A total of 1 billion US dollars has already been invested into these studies, including venture capital and other funding sources. How reasonable could the high expectations of scientific, clinical and business communities be? What obstacles should researchers and industries anticipate on their way to the market? Is this potential really high, or is it another soap bubble from the modern biotech?

Since 2005, as the term 'Genome editing' was coined [1], the field has developed, both in academic and industrial circles, towards the more efficient targeted nucleases which should possess optimal specificity, cost efficiency, and provide reproducible results. These advances resulted in development of the three main groups of relevant enzymes, i.e., zinc finger nucleases (ZFN), Transcription activator-like effector nucleases (TALEN), and CRISPR/Cas enzyme systems (CRISPR, Clustered Regularly Interspaced Short Palindromic Repeats; Cas, a CRISPR-associated protein). High accuracy of specific genome targeting by means of these molecular lancets led to present-day discovery of a novel research area which was designated as 'gene surgery'.

Broad outlooks of gene surgery have drawn immediate interest, first of all, in the medical field. Over the last decade, significant increase in the number of companies using different genome editing techniques has been observed. Their aim is to develop novel therapies for inherited monogenic, oncological and viral diseases. For instance, Sangamo Biosciences has developed a proprietary genome editing technology using ZFN system, and succeeded in Phase I clinical studies with HIV-infected patients, then extending potential indications to hemophilias, hemoglobinopathies, etc. [2]. French company Cellectis is developing TALEN in immuno-oncology. The idea is to edit immune cells for treatment of hemato-oncological disorders and some solid tumors [3]. The Editas Medicine activities are focused on genetic diseases, 
e.g. their first clinical trial scheduled for 2017 will concern Leber's amaurosis, a rare clinical form of blindness [4]. Caribou Biosciences studies different options for CRISPR-based technologies in medicine, agriculture, biological studies and industry, [5] whereas Intellia Therapeutics, their affiliated company, is seeking for ex vivo and in vivo genome editing for a number of clinical conditions [6]. CRISPR Therapeutics are focused on three main topics, (1) ex vivo gene editing of hematopoietic stem cells; (2) in vivo gene editing for liver diseases; (3) additional in vivo programs targeting other organ systems, such as muscle and lung [7].

All things considered, there is a new 'gold rush', this time centered on gene therapy. Investments to each of these companies are estimated in dozens and hundreds millions US dollars, whereas capitalization of the most advanced firms exceeds a billion USD. Meanwhile, appropriate clinical studies with different targeted nucleases enrolled less than 100 patients with viral and oncological diseases $[8,9]$. To date, several other clinical studies are endorsed [10], and vast majority of companies are only in the process of approaching clinical phase. Moreover, big industry, e.g., Novartis, AstraZeneca, Bayer, has also entered the game.

Several start-ups involved in genome editing have emerged in Russia. They are employed for medical applications of genome editing technologies. For instance, two Skolkovo resident companies are performing these activities, i.e., AGCT with a flagship project of hematopoietic stem cells gene editing aimed for the treatment of HIV-associated tumors [11], and the Gene Therapy Centre.

It is commonly known that intellectual property is the main asset of any company active in biotechnology and largely determines its market price and value. Proprietary rights for ZFN and TALEN are already established by the main players, thus forcing emerging companies to license the main patents, or to create new inventive solutions. Meanwhile, an uncertainty with intellectual property for CRISPR is characterized as a "patent battle" by most experts in the field. In May 2012, Jennifer Doudna, employed at the UC Berkeley filed a provisional patent application describing a new in vitro gene editing technique, jointly with Emmanuelle Charpentier (University of Vienna at that time) and other colleagues. In December 2012, Feng Zhang from the Broad Institute in Boston filed a provisional patent application for the specific use of CRISPR/Cas system exclusively in eukaryotic cells. Results of the both studies were reported in Science in August 2012 and February 2013, respectively [12, 13].

The first patent was finalized in March 2013, and the second one was finalized seven months later. However, the Broad Institute and MIT's joint patent was granted first in April 2014, due to the fast track requested by Zhang at the United States Patent and Trademark Office (USPTO). A year later, the UC Berkeley claimed to the USPTO on the patent interference right, demanding, at least, partial edition of the patent applied by Zhang, based upon the evidence that CRISPR use in eukaryotic cells presumed an obvious extension of the in vitro studies by Doudna and Charpentier. Over 2016, a big investigation has proceeded including analysis of a thousand of relevant documents offered by the both sides. The discus- sion is still ongoing, and appropriate decision is expected not earlier that in 2017.

However, despite the lack of clear-cut rights for intellectual property, and uncertainty of patent landscape, about ten emerging biotechnological companies based on CRISPR/Cas techniques have raised significant funding over last years. Some of them have already licensed intellectual property from their current owners while others are awaiting decisions on the legal conflicts. It is still unknown whether these decisions will influence the marketing processes and if the CRISPR-based genome editing will be widely available in the future. Currently three companies are leading in the field of CRISPR/Cas-based technologies applications in medicine, i.e., Editas Medicine, with Zhang as a co-founder, CRISPR Therapeutics, co-founded by Charpentier, and Intellia Therapeutics, an affiliated company by Caribou Biosciences, with Doudna as a co-founder.

Great expectations placed on these technologies are counterpoised by many open questions of the novel therapies efficacy and safety. Definite answers will be obtained only in the course of clinical trials which will determine successfulness of either research team.

In 2016, the story with CAR-T (T lymphocytes with chimeric antigen receptors) has forced the market players and general public to realize potential serious consequences of novel over-estimated approaches. A clinical trial performed by Juno Therapeutics was discontinued in July, due to severe neurotoxicity (i.e. cerebral edema) and lethal outcomes in three patients with acute lymphoblastic leukemia. This event caused immediate reaction among investors, researchers and society. The questions were raised on ethics and design of clinical studies by sponsors keeping the novel production technologies as a commercial secret, as well as claims for transparency from all the stakeholders, especially, in advanced fields of medicine [14]. The reasons were soon specified, the study protocol was amended appropriately, and so the trial was resumed. In November, however, two more lethal outcomes were reported by similar reasons, with repeated discontinuation of the clinical trial. Despite certain concerns, the challenges were only transient, both for Juno Therapeutics, and their competitors developing CAR-T for other applications (Kite Pharma, for non-Hodgkin lymphoma, Novartis), and the first approval of this technology is expected in the US in early 2017.

Outlooks for the CRISPR technology application for CAR-T production resulted into several joint R\&D programs: Editas Medicine in cooperation with Juno Therapeutics are developing novel gene-engineered $\mathrm{T}$ cells for cancer immunotherapy, whereas Novartis combined their efforts with Intellia Therapeutics, with a purpose of editing hematopoietic stem cells and design of novel CAR-T cells.

Complex approval procedures represent additional barriers for commercialization of new technologies, due to high-degree regulation in medicine and legal specifications in different countries. Moreover, some open questions remain, e.g., the issues of pricing, optimized manufacturing and quality control for the personalized products. Advances in tech- 
nologies definitely result into changes and improvement of regulatory standards. This is already true for gene therapy legislation in the USA and the EU $[15,16]$. Moreover, some special procedures for registration of breakthrough technologies are available in these countries, e.g., Prime in European Medical Agency (EMA), and Breakthrough Designation and Fast Track in Food and Drug Administration (FDA, USA). In Russian Federation, the Federal Law On Biomedical Cellular Products was issued in 2016 [17], which has fixed the regulatory frames for ex vivo gene editing technologies. Regulations for in vivo gene therapeutic techniques are generally determined in the Federal Law On Medicinal Drug Controls [18]. Emergence of novel technologies poses questions not only to the researchers but for the regulatory bodies as well. Certainly, a dialogue between the industry and regulators may accelerate clinical implementation of novel promising technologies aimed for the future treatment of serious and life-threatening diseases.

Rapid development and growing interest in genome editing have drawn attention of the community to this technology, both in the view of potential treatment advances of many severe disorders, as well as a source of numerous ethical dilemmas. The main aspect may concern opportunities for germinal cell and embryos editing at the preimplantation stage. Just in February 2016, Kathy Niakan from Francis Crick Institute obtained the first British licence for editing human embryos limited by research purposes only, in order to investigate fundamental mechanisms of normal and disturbed embryogenesis [19]. Quite recently, two research teams from China have reported the first successful cases of human embryo editing [20]. In the first case, the gene editing was performed due to an inherited blood disorder, and, in the second case, the procedure induced resistance against HIV. In both cases, the embryos were non-viable and were eliminated within several days. These events caused vivid discussions on rationale and relevance of human genome editing. On the one hand, such approach may potentially cure the child of an inherited disease, or make him non-susceptible to many infections. On the other hand, it may result in severe complications, since long-term effects of such interventions are still unknown. Moreover, there are concerns that in the future these procedures could be used for the consumer purposes, e.g. choice of eye color, or mental characteristics of the subject.

Modern legislation on the embryo editing varies in different countries, from total ban to biased interpretation of legal standards [21]. Hence, there is no answer to a question on the birthplace of the first "edited" child. The opinion leaders in this field have already replied to the social challenges and provided their comments, with respect to prospects of gene editing in germinal cells and embryos [22].

Technological breakthroughs, especially, in the field of biology and medicine, reveal a number of attractive outlooks, along with potential hazards. Only long-term studies may answer many current questions concerning human genome editing and we are lucky to live at the moment when we can observe and influence these changes.

\section{Conflict of interests}

The author has no conflicts of interest to be declared.

\section{References}

1. Urnov FD, Miller JC, Lee YL, Beausejour CM, Rock JM, Augustus S, Jamieson AC, Porteus MH, Gregory PD, Holmes MC. Highly efficient endogenous human gene correction using designed zinc-finger nucleases. Nature. 2005;435(7042):646-651.

2. http://www.sangamo.com/

3. http://www.cellectis.com/

4. http://www.editasmedicine.com/

5. http://cariboubio.com/

6. http://www.intelliatx.com/

7. http://crisprtx.com

8. Tebas P, Stein D, Tang WW, Frank I, Wang SQ, Lee G, Spratt SK, Surosky RT, Giedlin MA, Nichol G, Holmes MC, Gregory PD, Ando DG, Kalos M, Collman RG, Binder-Scholl G, Plesa G, Hwang WT, Levine BL, June CH. Gene editing of CCR5 in autologous CD4 T cells of persons infected with HIV. N Engl J Med 2014; 370(10):901-910.

9. Cyranoski D. CRISPR gene-editing tested in a person for the first time. Nature. 2016; 539:479.

10. Reardon S. First CRISPR clinical trial gets green light from US panel. Nature News. Jun 22, 2016.

\section{1. http://agct.bio}

12. Jinek M, Chylinski K, Fonfara I, Hauer M, Doudna JA, Charpentier E. A programmable dual-RNA-guided DNA endonuclease in adaptive bacterial immunity. Science. 2012; 337(6096):816-21.

13. Cong L, Ran FA, Cox D, Lin S, Barretto R, Habib N, Hsu PD, Wu X, Jiang W, Marraffini LA, Zhang F. Multiplex Genome Engineering Using CRISPR/Cas Systems. Science 2013; 339(6121):819-23.

14. Hey SP, Kesselheim AS. The FDA, Juno Therapeutics, and the ethical imperative of transparency. BMJ. 2016;354:i4435.

15. EMA: Guideline on the quality, non-clinical and clinical aspects of gene therapy medicinal products, 2015

16. FDA Guidance: Preclinical assessment of investigational cellular and gene therapy products, 2013; Potency tests for cellular and gene therapy products, 2014.

17. Russian Federal Law On Biomedical Cellular Products of 23/06/2016, No.180-Ф3 (as amended for 2016, in Russian).

18. Russian Federal Law On Medicinal Drug Controls of 12/04/2010, No.61-Ф3 (as amended for 2016, in Russian).

19. http://www.bbc.com/news/health-35301238

20. Callawey E. Second Chinese team reports gene editing in human embryos. Nature News. Apr 8, 2016. 


\title{
SHORT COMMUNICATIONS
}

21. Araki M., Ishii T. International regulatory landscape and integration of corrective genome editing into in vitro fertilization. Reprod. Biol. Endocrinol. 2014; 12:108.

22. Bosley KS, Botchan M, Bredenoord AL, Carroll D, Charo RA, Charpentier E, Cohen R, Corn J, Doudna J, Feng G, Greely HT, Isasi R, Ji W, Kim J-S, Knoppers B, Lanphier E, Li J, Lovell-Badge R, Martin GS, Moreno J, Naldini L, Pera M, Perry ACF, Venter JC, Zhang F, et al. CRISPR germline engineering - the community speaks. Nature Biotechnology. $2015 ; 33: 478-486$.

\section{Игры геномов: вызовы рынка, инвестиционный климат и патентные войны}

\author{
Кристина А. Ходова \\ Инновационный центр «Сколково», Москва, Российская Федерация
}

\section{Резюме}

Появление и совершенствование доступных технологий направленного редактирования генома открыло новые возможности для их потенциального терапевтического применения в различных областях медицины. Несмотря на ранние стадии большинства разработок в этой области, они могут изменить не только подходы к лечению многих тяжелых заболеваний, но и уже влияют на формирование рыночного ландшафта и развитие общества в целом. Основной вопрос состоит в том, насколько оправданы надежды ученых, разработчиков и инвесторов на эти продукты и результаты, и какие основные риски ожидают на пути регистрации и внедрения нового продукта в клиническую практику.

\section{Ключевые слова}

Редактирование генома, инвестиции, стартапы, исследования и разработки, интеллектуальная собственность. 